\title{
Assessment of durum wheat (Triticum durum Desf.) genotypes based on their agro-physiological characteristics and stress tolerance indices
}

\author{
Radhia MEKAOUSSI ${ }^{1}$, Abou-bakr RABTI ${ }^{2}$, Zine El Abidine FELLAHI ${ }^{3}$, Abderrahmane HANNACHI ${ }^{4}$, \\ Amar BENMAHAMMED ${ }^{5}$, Hamenna BOUZERZOUR ${ }^{5}$
}

Received January 03, 2020; accepted March 15, 2021.

Delo je prispelo 3. januarja 2020, sprejeto 15. marca 2021.

\begin{abstract}
Assessment of durum wheat (Triticum durum Desf.) genotypes based on their agro-physiological characteristics and stress tolerance indices

Abstract: The present study aimed to investigate the extent of variability and relationships between grain yield and morpho-physiological durum wheat traits. Sufficient variability was observed for most characters. Based on stress indices, either widely or specifically, adapted lines were identified. Path analysis pointed out to above ground biomass, harvest index, spike fertility and spike number as yield determinants, suggesting that these traits are of interest in the breeding program. The measured traits were classified within 6 principal components accounting for $79.45 \%$ of the total variation. Breeding lines dispersed along first principal component exhibited substantial differences in performance and stress tolerance abilities. Cluster C3 lines were high yielding and stress tolerant. From this cluster, lines L24 and L14 were scored as the best for 7 and 5 traits out of 17 characters, respectively. Both lines are proposed for release and as parents in crosses to take advantage of their desirable characteristics. The results indicated that physiological traits were unrelated to each other and to morphological traits making difficult the concomitant selection for yield and stress tolerance driven by these traits. Complexes crosses, between parents carefully chosen for these specific characteristics, are necessary to enhance favorable genetic linkage and to generate new basic segregating populations with high genetic variability for these traits.

Key words: Durum wheat; grain yield; genotype $\mathrm{x}$ environment interaction; physiological traits; tolerance indices; path analysis; cluster
\end{abstract}

Ovrednotenje genotipov trde pšenice (Triticum durum Desf.) na osnovi agro-fizioloških lastnosti in indeksov tolerance na stres

Izvleček: Namen te raziskave je bil preučiti obseg spremenljivosti in razmerja med pridelkom zrnja in morfološkofiziološkimi lastnostmi trde pšenice. Za večino lastnosti je bila ugotovljena zadostna variabilnost. Na osnovi indeksov stresa so bile določene širše in ožje prilagojene linije. Analiza povezanih znakov je pokazala, da so nadzemna biomasa, žetveni indeks, fertilnost klasov in njihovo število najpomembnejše lastnosti, ki določajo pridelek, kar kaže, da so te lastnosti zanimive za žlahtnjiteljske programe. Merjene lastnosti so bile razvrščene znotraj 6 glavnih komponent, kar je prispevalo kar 79,45\% celokupne variabilnosti. Linije križancev razvrščene vzdolž prve glavne komponenete so imele znantno raznolikost glede sposobnosti tolerance na stres. Linije v grozdu C3 so bile tolerantne na stres in imele velik pridelek. Iz te skupine sta bili liniji L24 in L14 prepoznani kot najboljši za 7 in 5 znakov izmed 17 lastnosti. Obe liniji sta predlagani prednostno za uporabo v križanjih kot starševski liniji zaradi njunih zaželjenih lastnosti. Izsledki so pokazali, da fiziološke lastnosti niso bile povezane med sabo niti z morfološkimi znaki, kar povzroča težave pri hkratni selekciji za pridelek in toleranco na stres na osnovi teh lastnosti. Za povečanje genetske povezave med preučevanimi znaki in vzgojo novih osnovnih raznolikih populacij so potrebna kompleksna križanja med pazljivo izbranimi starši, glede na te specifične lastnosti.

Ključne besede: trda pšenica; pridelek zrnja; interakcije genotipa in okolja; fiziološke lastnosti; indeksi tolerance; analiza povezanih znakov; klasterska analiza

1 Department of Agronomy, Valorization of Natural Biological Resources Laboratory, Faculty of Natural and Life Sciences, University of Ferhat Abbas Setif-1, 19000 Setif, Algeria

2 Institute of Agriculture and Veterinary Sciences, University of Mohamed-Cherif Messaadia, 41000 Souk Ahras, Algeria

3 Department of Agronomy, Faculty of Natural, Life and Earth Sciences and the Universe, University of Mohamed El Bachir El Ibrahimi, 34034 Bordj Bou Arreridj, Algeria

4 National Agronomic Research Institute of Algeria (INRAA), Setif Research Unit, 19000 Setif, Algeria

5 Department of Ecology and Plant Biology, Valorization of Natural Biological Resources Laboratory, Faculty of Natural and Life Sciences, University of Ferhat Abbas Setif-1, 19000 Setif, Algeria

Corresponding author, e-mail: zinou.agro@gmail.com / zineelabidine.fellahi@univ-bba.dz 


\section{INTRODUCTION}

Durum wheat (Triticum durum Desf.) is a major cereal crop grown in Algeria. Its production is based on adoption of modern varieties derived from CIMMYT (International Maize and Wheat Improvement Center) plant material and traditional cultivars issued from heritage landraces. Actually 1.5 million hectares are sown annually with a production varying from $0.42(1986 / 87)$ to 3.2 million tons (2016/17), during the 1975-2017 period (CEIC, 2021). Because of differential ability to withstand drought and heat stresses, traditional cultivars are generally grown in poor yielding environments while recently released varieties are cultivated under relatively more favorable conditions. Sown in autumn, as rainfed crop, the vegetative growth phase occurs during cold and wet winter-early spring months while reproductive growth phase endures drought and terminal heat stresses. To meet the needs of a fast-growing population and to reduce the sharp rise in grain imports, larger production increases are sought. Since increasing sown area is not possible, future improved durum wheat varieties must then be capable of higher yields under lower management and uncertain climate scenarios. Because of climate changes, declining rainfall and increased temperatures are predicted for the Mediterranean basin which is likely to be a vulnerable hotspot (Lobell et al., 2007; Fraser et al., 2013).

Beside high yield potential, new cultivars should express stable performance and broad adaptation. Grain yield is a result of the combined effects of genotype (G), environment (E), and their interaction (GEI). Differences among genotypes, in their response to environmental changes, are caused by GEI (Annicchiarico et al., 2005; Haddad et al., 2016). A crossover GEI type reduces heritability and selection efficiency (Ceccarelli et al., 1991). Substantial efforts are therefore dedicated to reduce yield instability through plant breeding and crop management (Chamekh et al., 2015). A number of traits and indices have been proposed to be used along with grain yield to select more efficiently desirable genotype characterized by high yield potential, stress tolerance and acceptable stability (Li et al., 2012; Dorostkar et al., 2015). In this context, an understanding of the physiological mechanisms underlying abiotic stress tolerance, the identification of the trait-markers of these mechanisms and the analysis of their relationships with grain yield and yield attributes could be helpful to efficiently select for high and stable grain yield under variable environments. Plants have developed several mechanisms, which alleviate the harmful effects of stress (Ashraf, 2010). Among various environmental stresses, heat and drought are the main grain yield limiting factors. Yield reduction mag- nitude depends on plant growth stage subjected to stress and on stress severity (Nouri et al., 2011). Differences in stress tolerance among genotypes and species were reported in several studies (Marcinska et al., 2017; Grzesiak et al., 2012; 2017). Yield stability indices have been formulated and proposed among others by Di-Matteo et al. (2016) and Farshadfar et al. (2018).

The relation between grain yield obtained under stress and non stress conditions could be used as marker of stress tolerance. This relation is approached through stress tolerance indices, which identify genotypes with good performance under both non-stress and stress environments (Benmahammed et al., 2010; Grzesiak et al., 2012). Stress tolerance (STI), yield stability (YSI) and superiority genotypic $(\mathrm{Pi})$ indices were, among several other indices, proposed as potential tools to identify high yielding, stable and/or stress tolerant genotypes (Lin and Binns, 1988, Farshadfar et al., 2018). Stress-induced cell membrane injury, relative water contain, rate of excised flag leaf water loss, canopy temperature, and leaf chlorophyll contain were rated as promising screening tools in the search of stress tolerance (Hura et al., 2007; Hasheminasab et al., 2014; Saed-Moucheshi et al., 2016). In this context, Awan et al. (2015) reported that grain yield was closely linked to relative water content, cell membrane stability and specific flag leaf area. The increased solute leakage, marker of decreased cell membrane thermostability, is used as a measure of heat-stress tolerance (Wahid et al., 2007; Khajuria et al., 2016). The present investigation aimed to assess the variability, stability and relationships of grain yield with physio-morphological traits in a set of durum wheat (Triticum durum Desf.) advanced breeding lines grown under south Mediterranean conditions.

\section{MATERIAL AND METHODS}

\subsection{SITE, PLANT MATERIAL, AND EXPERIMEN- TAL DESIGN}

Twenty four advanced durum wheat breeding lines and a check, cultivar Waha (Table 1), were evaluated in a field experiment during the 2016/17, 2017/18 and 2018/19 growing seasons at the Field Crop Institute, Agricultural Experimental Station of Setif (ITGC-AES, $36^{\circ} 12^{\prime} \mathrm{N}, 05^{\circ} 24^{\prime} \mathrm{E}, 1080 \mathrm{~m}$ above sea level, Setif, Algeria). The experiment was set-up in a randomized complete block design with four replications. Plot dimensions were 6 rows $5 \mathrm{~m}$ long with $0.20 \mathrm{~m}$ space between adjacent rows, and $0.30 \mathrm{~m}$ between adjacent plots. Recommended cultural practices for the area were followed to grow a good crop. Eighty kg ha-1 of mono-ammonium phosphate (52 
$\% \mathrm{P}_{2} \mathrm{O}_{5}+12 \% \mathrm{~N}$ ) were applied just before sowing, and $80 \mathrm{~kg} \mathrm{ha}^{-1}$ of urea $(46 \% \mathrm{~N})$ were broadcasted at the tillering stage. Weeds were controlled chemically by application of $150 \mathrm{~g} \mathrm{ha}^{-1}$ of Zoom (Dicamba $66 \%$, Triasulfuron $4 \%)$ and $1.21 \mathrm{ha}^{-1}$ of Traxos (22.5 $\mathrm{gl}^{-1}$ of Pinoxaden, 22.5 $\mathrm{g} \mathrm{l}^{-1}$ of Clodinafopropargyl and $6.5 \mathrm{~g}^{-1}$ of Cloquintocet -mexyl) herbicides.

\subsection{WEATHER CONDITIONS}

Monthly rainfall and temperatures (maxi, mini, and average) recorded at the experimental site, during the three cropping seasons, are reported in Figure 1. Rainfall distribution, typical of Mediterranean climate, is quite variable within and between cropping seasons. The amount recorded, from September $1^{\text {st }}$ to June $30^{\text {th }}$, reached 187.5, 442.1 and $346.6 \mathrm{~mm}$, for 2016/17, 2017/18 and 2018/19 cropping seasons, respectively. Expressed relatively to the maximum value, these figures represent $42.4,100.0$ and $78.4 \%$, for the three cited cropping seasons, respectively. Rainfall amount available for the vegetative phase ranged from $73.2 \%$ to $83.1 \%$ of the cycle total, and from 16.9 to $26.8 \%$ for the reproductive phase. Rainfall of the $2017 / 18$ cropping season was evenly distributed along the crop cycle, while in $2016 / 17$, a severe drought period occurred from the tillering stage onwards. June 2017 showers, coinciding with the grain filling period, avoided a complete crop failure. In fact, with less than $15 \mathrm{~mm}$, during the March-April-May period, the 2016/17 cropping season was a stressful environment, while with $223.6 \mathrm{~mm}$ accumulated during the same period, the 2017/18 cropping season behaved as a favorable environment for wheat growth. Monthly mean maximum, mean minimum temperatures and their average exhibited, during the crop cycle, a bimodal evolution pattern, reaching their lowest values in January and February months and their highest values in June onwards (Figure 1). Under this climatic scenario, durum wheat growth is hampered by low temperature during the vegetative phase, when relatively appreciable soil water is available and by rising temperatures and water scarcity during the grain filling phase.

\subsection{DATA COLLECTION}

Relative water content $(R W C)$ was determined as described in Pask et al. (2012). Fresh leaves were collected, at anthesis, weighted to record fresh mass (FM). The samples were placed in distilled water for $24 \mathrm{~h}$ and weighed to record turgid mass (TM). Samples were then subjected to oven drying at $72{ }^{\circ} \mathrm{C}$ for $24 \mathrm{~h}$ to record dry mass (DM). Relative water content was calculated as follow: $R W C=[(F M-D M) /(T M-D M)] \times 100$. Flag leaf chlorophyll content (CHL, CCI) was determined with a CCM - 200 chlorophyll meter (Opti-Sciences, Tyngsboro, MA, USA) at the anthesis growth stage. Chlorophyll measurements were taken from the middle of the flag leaf. Canopy temperature (CT) was measured, at heading, using a hand-held infrared thermometer (Fluke Corporation, Everett, WA, USA). Four measurements were taken per plot at approximately $0.5 \mathrm{~m}$ distance from plot edge. Readings were done between 11:00 to 14:00 hours on sunny days.

Table 1: Name and pedigree of the advanced durum wheat breeding lines tested during three successive cropping seasons $(2016 / 17,2017 / 18,2018 / 19)$ at the ITGC- AES experimental site (Setif, Algeria).

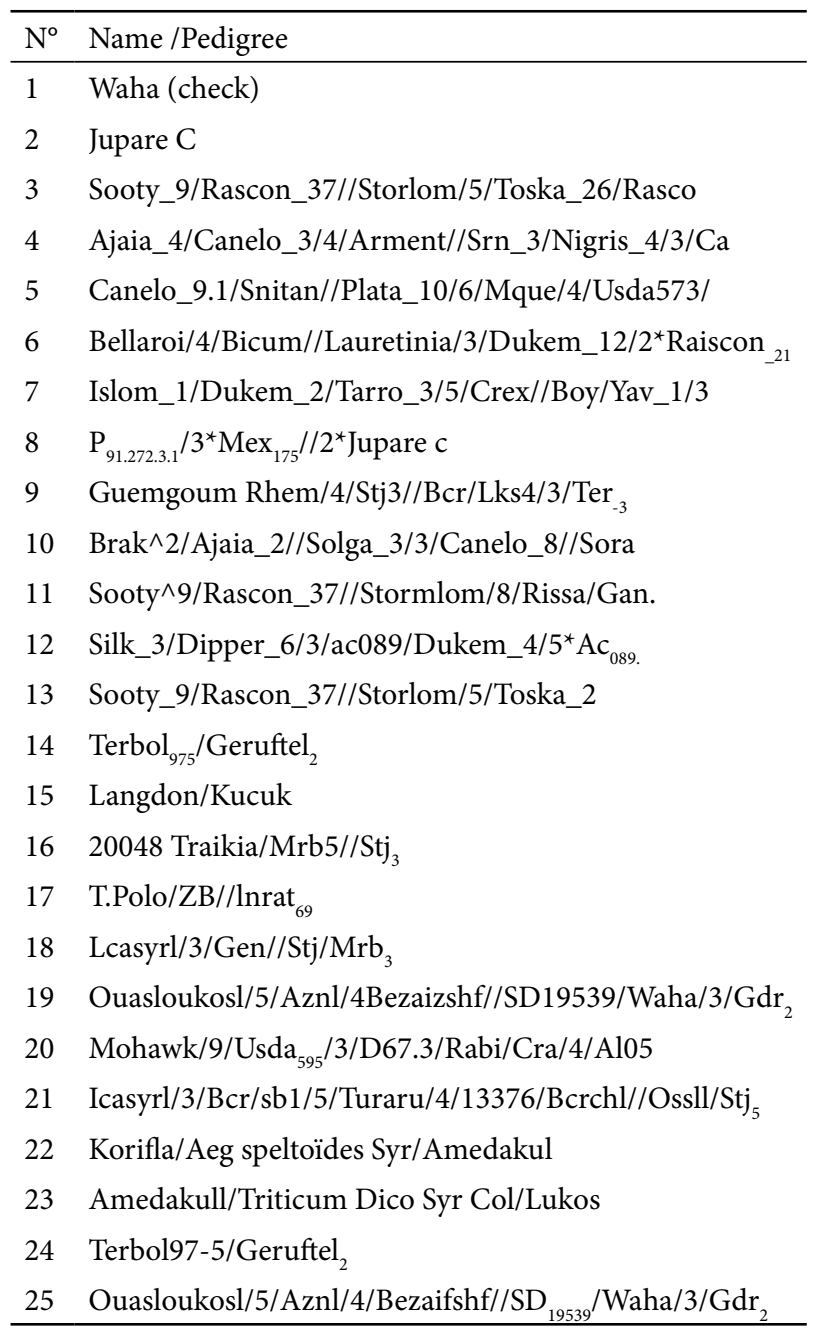




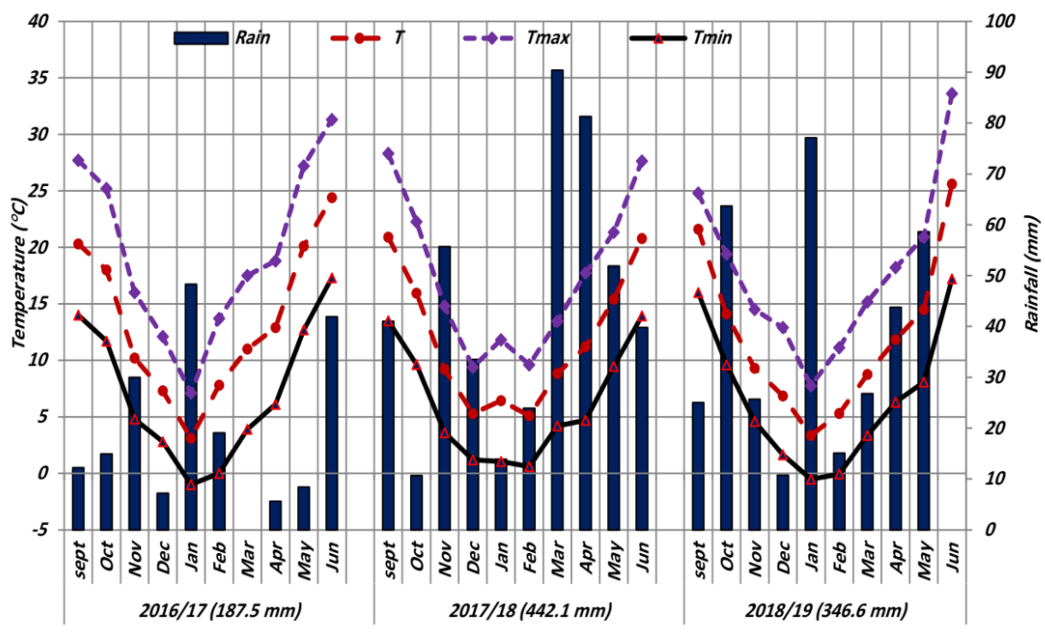

Figure 1: Monthly rainfall and mean temperatures recorded during the three cropping seasons test at the ITGC-AES, Setif, Algeria.

Membrane stability index (MSI) was estimated according to Ibrahim and Quick (2001). Two sets of leaf tissues, 10 leaf segments, $1 \mathrm{~cm}$ length each, were placed in test tubes containing $10 \mathrm{ml}$ of double-distilled water. One set was kept at $40{ }^{\circ} \mathrm{C}$ for $30 \mathrm{~min}$ and its electrical conductivity recorded (C1) using a conductivity meter, type Eutech Instruments, Singapore, while the second set was kept in a boiling water bath $\left(100{ }^{\circ} \mathrm{C}\right)$ for $30 \mathrm{~min}$ and its conductivity recorded (C2). MSI was calculated as follows: $M S I=100 *[1-(\mathrm{C} 1 / \mathrm{C} 2)]$. To determine the rate of excised leaf water loss (ELWL), 10 flag leaves were randomly clipped per plot, and were immediately weighted to record the fresh mass (FM). The samples were wilted at $30{ }^{\circ} \mathrm{C}$ in an electrical oven for 4 hours, and weighted to obtain the wilted mass (WM). The samples were oven-dried at $70{ }^{\circ} \mathrm{C}$ for $72 \mathrm{~h}$ and weighed to record dry mass $(\mathrm{DM})$. ELWL was worked out using the following formulae: ELWL $(\%)=100 *(F M-W M) / D M$ (Dhanda and Sethi, 1998). Plants were scored for plant height (PHT, cm), measured just before harvest. Days to heading (DHE) were counted from January $1^{\text {st }}$ to the date when $50 \%$ of the spikes were half-way out of the flag leaf sheath. At maturity, a row segment, $1 \mathrm{~m}$ long, was harvested and used to determine above ground biomass $\left(\mathrm{BIO}, \mathrm{g} \mathrm{m}^{-2}\right)$, number of spikes $\mathrm{m}^{-2}(\mathrm{SN})$, and harvest in$\operatorname{dex}(\mathrm{HI}, \%)$. Grain yield (GY, $\mathrm{g} \mathrm{m}^{-2}$ ) and thousand-kernel mass (TKM, g) were determined from the combine harvested trial. The number of kernels per spike (NKS) was derived as the ratio of the number kernels $\mathrm{m}^{-2}$ divided by the number of spikes $\mathrm{m}^{-2}$.

\subsection{DATA ANALYSIS}

Environment (E), genotype $(\mathrm{G})$ and their interac- tion (GEI) effects of physiological, yield and yield-related traits were determined through a combined analysis of variance using balanced analysis of variance subroutine implemented in Cropstat software (Cropstat, 2007). Genotypic $\left(\sigma_{\mathrm{G}}^{2}\right)$ and error $\left(\sigma^{2} \mathrm{e}\right)$ components of variance were calculated to estimate the coefficient of experimental $(\mathrm{CVe})$, and of genotypic variation $\left(\mathrm{CV}_{\mathrm{G}}\right)$ and their ratio $\mathrm{CV}_{\mathrm{G}} / \mathrm{CVe}$. This ratio is used to appreciate the magnitude of genotypic relatively to experimental variation as suggested by Cruz et al. (2012). A ratio value, greater than unity, suggests the presence of appreciable genotypic variability exploitable in selection. Pearson's correlation coefficients between grain yield and the measured traits were calculated per cropping season using Past software (Hammer et al., 2001). Path coefficients analysis was carried out on the across cropping seasons averaged values. For this purpose, mean values of the traits loaded in the full model were standardized, and subjected to a multiple regression analysis to determine standardized partial regression coefficients (Beta) or paths. The indirect effect of trait $X_{i}$ via trait $X_{j}$, was obtained as the product of the path coefficient of the trait $X_{i}$ and the correlation coefficient relating traits $X_{i}$ and $X_{j}$, following the procedure described in Akintunde (2012). Genotypic superiority index $(\mathrm{Pi})$ was derived according to Lin and Binns (1988) as: $P_{i}=\Sigma\left(X_{i j}-M_{j}\right)^{2} / 2 \mathrm{n}$, where $X_{i j}$ is the grain yield of the $i^{\text {th }}$ breeding line in the $j^{\text {th }}$ testing environment (cropping season), $M_{j}$ is the grain yield of the best performing breeding line in the $j^{\text {th }}$ environment, and $\mathrm{n}$ is the number of environments test. Grain yield stability index (YSI) was calculated using the following formulae: $Y S I=Y s / Y p$; and stress tolerance index (STI) was determined as follow: $S T I=(Y p \times Y s) / \bar{Y} p^{2}$, where Ys, Yp and $\bar{p}$ are grain yield means observed under stress, non stress and average of all assessed breeding lines under non stress envi- 
ronments, respectively (Benmahammed et al., 2010). The ecovalence $\left(\mathrm{W}^{2} \mathrm{i}\right)$ was calculated as described in Weedon and Finckh (2019) as follow: $W_{i}^{2}=\sum\left(X_{i j}-X_{i .}-X_{. j}+X_{.}\right)^{2}$, where $X_{i j}$ represents grain yield of the $i^{i t h}$ genotype in the $\mathrm{j}^{\text {th }}$ environment, $X_{i .}$ is the genotype main effect, $X_{. j}$ is the environment main effect and $X$ is the grand mean. Principal components and cluster analyses, subroutine implemented in Past statistical software (Hammer et al., 2001), were carried out using standardized mean values of the measured traits averaged of across environments and the stress index values. Dendrogram, showing breeding lines classification, was generated adopting Ward's method based on squared Euclidean distance.

\section{RESULTS AND DISCUSSION}

\subsection{MEAN PERFORMANCE AND VARIABILITY}

The results of the combined analysis of variance for the measured traits are reported in Table 2. Season and genotype main effects as well as their interaction (GEI) were highly significant for all traits, except CHL season main effect and GEI which were not. Season main effect of GY, NKS, DHE, BIO, and PHT accounted for more than $70.0 \%$ of the variation observed in the analyzed data. Season main effect of HI, SN and MTS explained between 30.0 to $60.0 \%$ of the total variation expressed in these traits, while TKM, RWC and CHL season main effects accounted for less than $30 \%$ of the total variation. Genotype main effect accounted for $15.0 \%$ for GY, SN, NKS, DHE, BIO, HI and RWC. TKM and CHL genotype main effect accounted for $52.2 \%$, and $23.1 \%$, to the total variation, respectively. Contribution of GEI to the total variation was as low as $1.2 \%$ and $2.7 \%$ for PHT and DHE and increased to $38.5 \%$ for HI (Table 2). These results suggested that the expression of the measured traits is affected essentially by changes in environment, while variation originated from differences between genotypes (G) and GEI effects is comparatively less marked. The large season main effect is attributed to differences in the amount and distribution of annual rainfall (Figure 1). The fact that GEI contributed more to the explanation of the variation observed than the contribution due to genotype main effect suggested that genotypes responded and ranked differently across the seasons test, as this is shown in Figure 2, which indicated the G + GEI contribution to the grain yield variation.

Breeding line L19 was the most reacting, exhibiting positive contribution during two seasons and a strong negative contribution during the third season. L9 appeared as a desirable entry as it exhibited positive contributions during the three cropping seasons. L6, L3 and to a lesser extent L4 were less yielding but have positive interactions during the three cropping seasons (Figure 2 ). The results of the present study show that selection and recommendation, based on grain yield of superior genotypes among those tested, is difficult because of the masking effect of the GEI.

The mean, maximum and minimum values, averaged over seasons, and the best scoring lines for the measured traits are reported in Table 2. GY ranged from 585.93 to $838.11 \mathrm{~g} \mathrm{~m}^{-2}$, SN from 435.42 to 590.42 , TKM from 33.08 to $41.17 \mathrm{~g}$, NKS from 29.23 to 41.32 kernels per spike, DHE from 113.33 to 117.33 days, BIO from 1334.98 to $1976.38 \mathrm{~g} \mathrm{~m}^{-2}$, HI from 34.45 to $47.53 \%$, PHT from 65.23 to $71.18 \mathrm{~cm}$, RWC, from 66.90 to $83.01 \%$, MTS from 49.44 to $71.43 \%$, CHL from 33.78 to 46.36 cci, CT from 20.15 to $24.90^{\circ} \mathrm{C}$ and ELWL from 23.58 to $55.32 \%$. The recorded values for the coefficient of experimental variation $(\mathrm{CVe})$ were below $10 \%$ for most of the measured traits, suggesting that an appreciable precision was achieved in the measurement of these traits. CVe values for HI, RWC, MTS, CHL and ELWL were higher than $10 \%$ suggesting a lack of precision and an environment effect on the expression of these traits. Increasing replications for the measurement of these traits is justified to be able to detect significant genotypic differences, if any. The ratio $\mathrm{CV}_{\mathrm{G}} / \mathrm{CVe}$ is almost equal to 1 for $\mathrm{CT}$ and higher than unity for TKM and DHE, indicating sizeable genotypic variability. Values of this ratio were lower than unity for the remaining measured traits, suggesting relatively low genotypic variability.

\subsection{GRAIN YIELD STABILITY AND STRESS TOLERANCE}

Genotypic superiority index values ranged from 1.46 to 52.12 with an average of 33.41 . The best breeding lines ( $\approx 10 \%$ selection intensity) were L24 and L13 which exhibited the lowest Pi values of 1.5 and 8.4, respectively. YSI values ranged from 0.219 to 0.553 and an overall mean of 0.330 . Since high YSI values are desirable, the best breeding lines for this trait were L25 (YSI $=0.180$ ) and L19 (YSI $=0.553$ ). STI values ranged from 0.184 to 0.439 and an overall mean of 0.324 . High STI values are desirable in selection for drought tolerance. The best breeding lines for this trait were L1 $($ STI $=0.439)$ and L11 (STI $=0.423)$. The ecovalence values $\left(\mathrm{W}^{2} \mathrm{i}\right)$ ranged from 3.03 to 120.0 with an average value of 25.34. Genotypes exhibiting low $\mathrm{W}^{2} \mathrm{i}$ are desirable in selection. The best breeding lines for this characteristic were $\mathrm{L} 15\left(\mathrm{~W}^{2} \mathrm{i}=\right.$ $3.00)$ and $\mathrm{L} 21\left(\mathrm{~W}^{2} \mathrm{i}=7.1\right)$. Correlation coefficients analysis indicated that no significant relationship $(r=0.164, p$ $>0.05$ ) existed between Yp (GY of 2017/18 season) and 


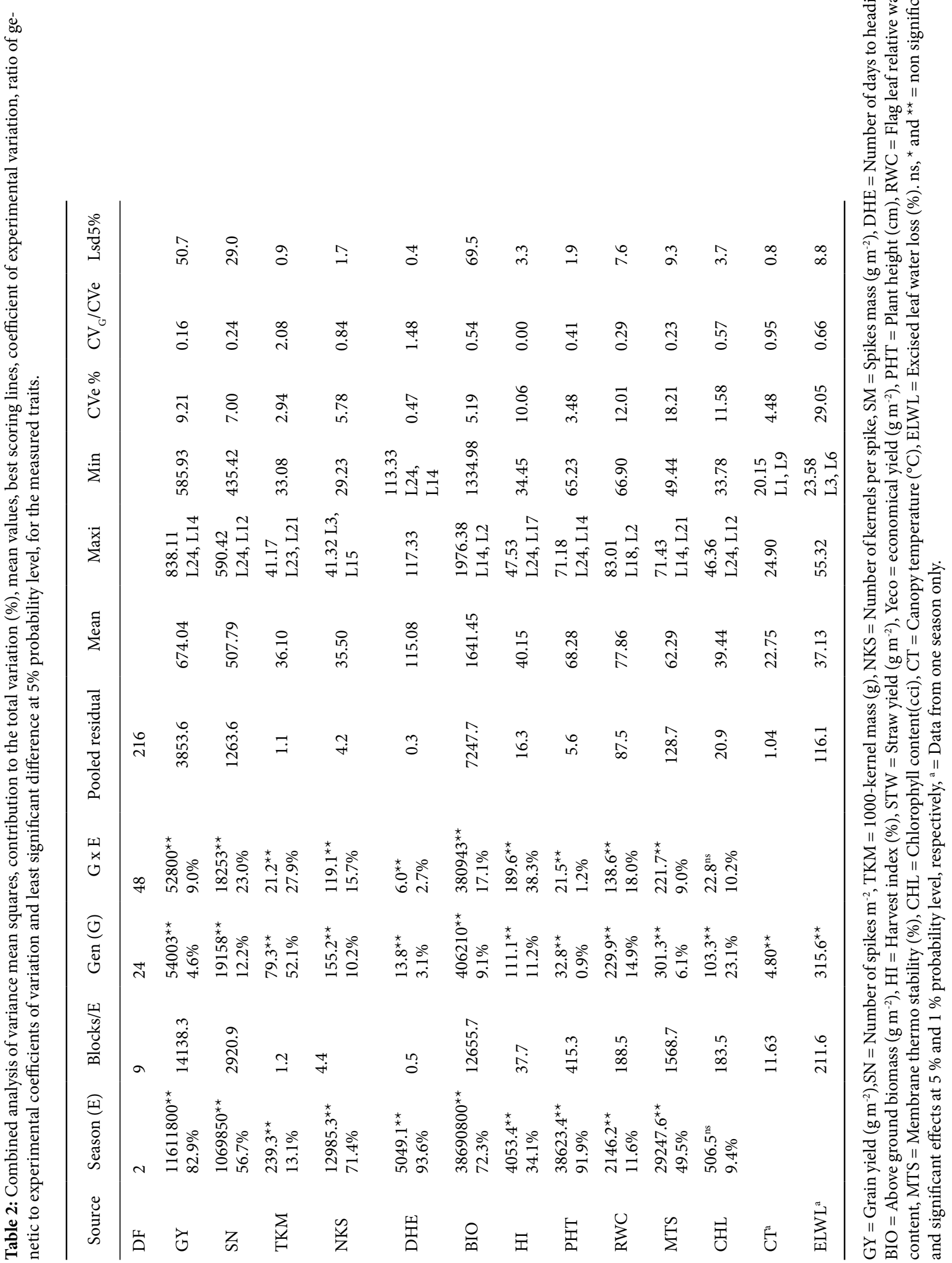




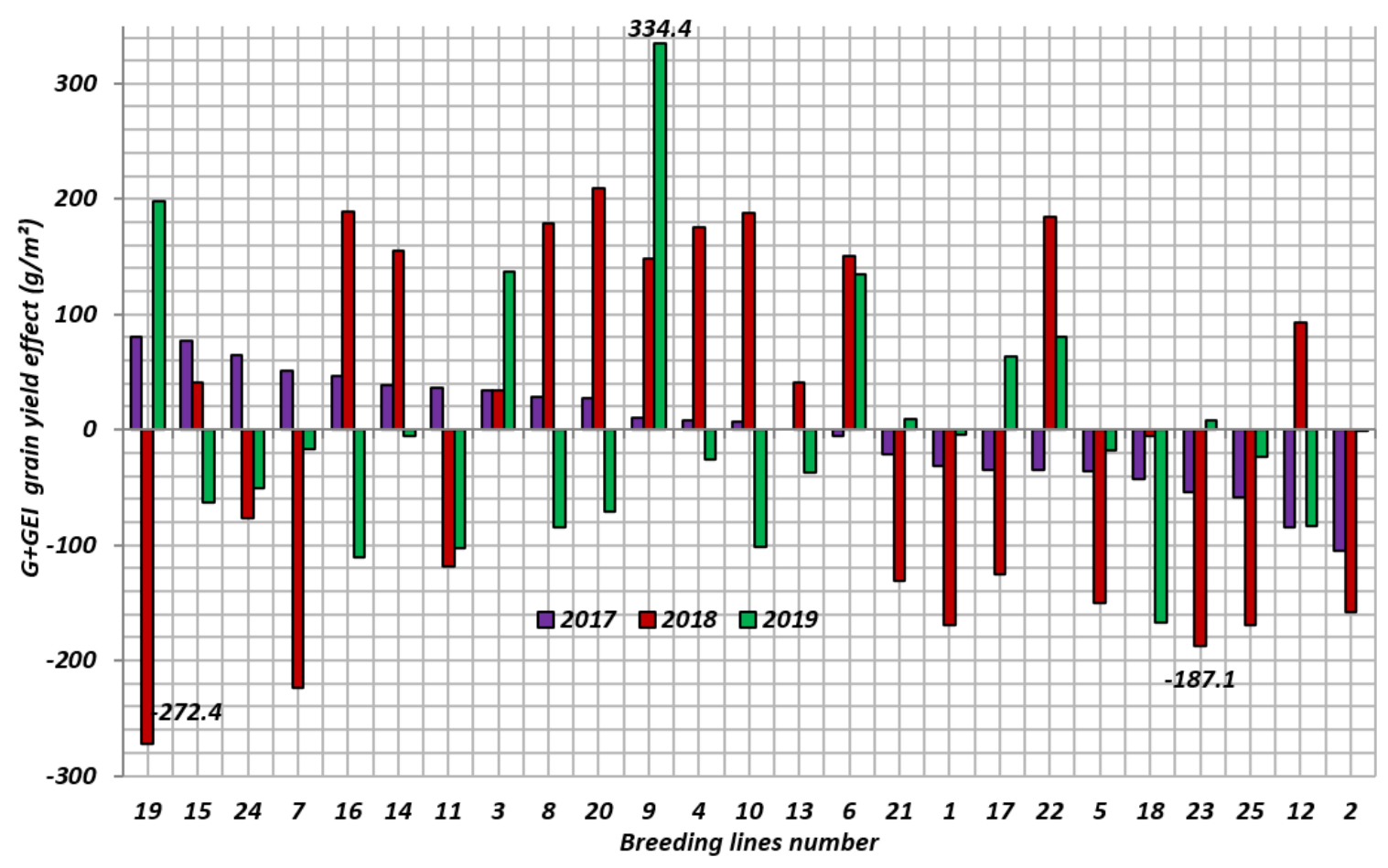

Figure 2: Genotype + Genotype $x$ Environment interaction (G + GEI) contributions to grain yield variation of the advanced breeding lines assessed during three cropping seasons at the ITGC-AES of Setif (Algeria).

Ys (GY of 2016/17 season), suggesting that both environments ranked differently the assessed breeding lines. These results support findings reported by Nouri et al. (2011). In contrast, a positive and significant correlation, between Ys and Yp, was reported by Golabadi et al. (2006) and a negative one by Sio-Se-Mardeha et al. (2006). Different results may come out due to the nature of the GEI present (presence of crossover or not), stress intensity and to the degree of sensitivity of the plant materials tested. Pi index correlated negatively and significant with $\mathrm{Yp}$ $(\mathrm{r}=-0.725, p<0.01)$ and with STI $(\mathrm{r}=-0.629, p<0.01)$, but not with YSI $(\mathrm{r}=0.384, p>0.05)$, nor with $\mathrm{W}^{2} \mathrm{i}(\mathrm{r}$ $=-0.027, p>0.05)$.YSI index correlated negatively and significant with $\mathrm{Yp}(\mathrm{r}=-0.641, p<0.01)$ and positively and significantly with $\mathrm{Ys}(\mathrm{r}=0.637, p<0.01)$ and with $\mathrm{W}^{2} \mathrm{i}(\mathrm{r}=0.470, p<0.05)$. Besides its negative and significant correlation with $\mathrm{Pi}$, STI index correlated positively and significant with $\mathrm{Ys}(\mathrm{r}=0.717, p<0.01)$ and $\mathrm{Yp}(\mathrm{r}=$ $0.800, p<0.01)$. Pi index measures the deviation of the performance of a given genotype from that of the best performing genotype in a given environment, and lower Pi values are desirable, because they identify high yielding and stable genotypes (Lin et Binns (1988).

The results of the present study corroborate those of Clarke et al. (1992) and Benmahammed et al. (2010) who reported significant and negative correlation between
Pi and Yp. This correlation suggested that low Pi genotypes responded to improved growth conditions (fertility) more than they do under stress conditions which are less discriminating. Yield stability index (YSI) measures Ys as a fraction of Yp. Genotypes, with high YSI index, minimize yield decline under stressed conditions. The results of the present study corroborate those of Nouri et al. (2011) who reported a negative and significant correlation between YSI and Yp and a strong positive and significant correlation with Ys. Similar results were obtained by Sio Se-Mardeh et al. (2006). The positive and significant correlation between YSI and $\mathrm{Wi}$, found in the present study, suggests that YSI identify stable genotypes too. Nouri et al. (2011) and Mohammadi et al. (2011) mentioned that STI was suitable for sorting out the best yielding and stable genotypes under Ys and Yp growth conditions. According to Lin et al. (1986), $\mathrm{W}^{2} \mathrm{i}$ represents the genotypic contribution to the GEI, as such a $\mathrm{W}^{2} \mathrm{i}$ value near or equal to zero is suggestive of dynamic stability. No significant correlations were found, in the present study, between $\mathrm{W}^{2} \mathrm{i}$ and $\mathrm{Ys}$, nor between $\mathrm{W}^{2} \mathrm{i}$ and Yp. In this context Benmahammed et al. (2010) report a positive and significant correlation between $\mathrm{W}^{2} \mathrm{i}$ and $\mathrm{Yp}$, suggesting that best performing genotypes under favorable environment are generally instable. Non significant correlation between $\mathrm{Yp}$ and $\mathrm{W}^{2} \mathrm{i}$ indicates the independ- 
ence of this stability parameter from grain yield under non stress conditions and the potential trade-off between grain yield potential and stability as mentioned by Lopes et al. (2012). Comparison of Ys and Yp of the advanced breeding lines selected on the basis of the studied indices indicated that STI and Pi identify high yielding and stable genotypes which take advantage of the growth conditions available in the favorable environment (Figure 3).

Selection based on YSI identifies genotypes which minimize Ys decline at the expense of Yp which is drastically reduced. Selection, based on $\mathrm{W}^{2} \mathrm{i}$ identifies stable genotypes which deviate little from the grand mean (Figure 3). These results corroborated those of Weedon and Finckh (2019) who reported that $\mathrm{W}^{2} \mathrm{i}$ identifies stable genotypes which exhibit low GEI, achieving a yield response parallel to the mean yield response of all genotypes. These results suggest that selection based on $\mathrm{W}^{2} \mathrm{i}$ and YSI parameters favors stable but below average yielding genotypes. In contrast, selection based on Pi and STI favors high-yield genotypes adapted to a wide range of conditions. Yield stability is either static or dynamic. Genotypes showing static stability tend to yield similarly across all environments, showing specific adaptation to stress environments. Genotypes showing dynamic stability exhibit a mean response parallel to the mean response of all genotypes in the test environments. They are adapted to a broader range of environments.

\subsection{GRAIN YIELD AND MORPHO- PHYSIOLOGICAL TRAITS RELATIONSHIPS}

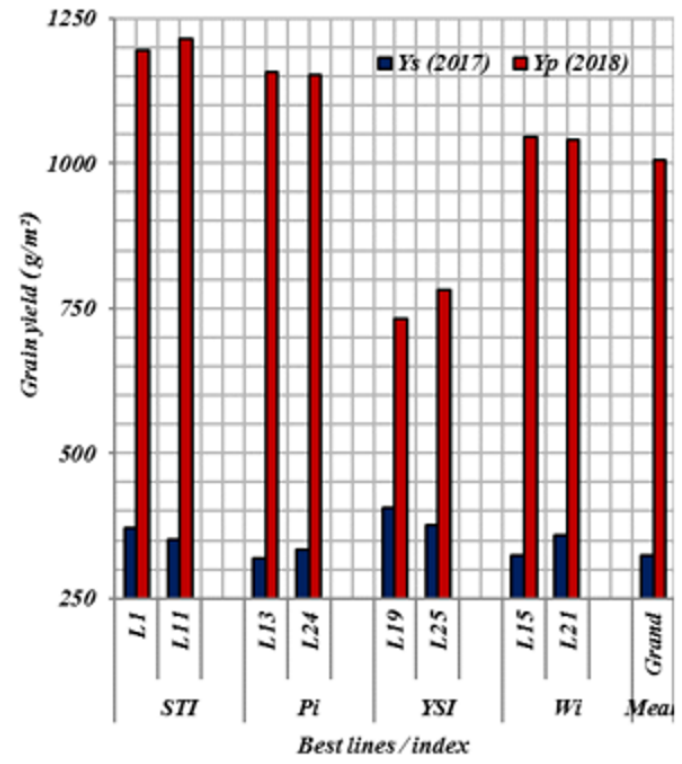

Correlation coefficients analysis per environment indicated consistent positive and significant correlations across seasons $(\mathrm{r}=0.446, p<0.05 ; \mathrm{r}=0.641, p<0.01$ and $\mathrm{r}=0.615, p<0.01)$ between GY and SN, suggesting that $\mathrm{SN}$ exerted a strong influence on grain yield. The relationships between GY, on one hand, and NKS, BIO and HI, on the other hand, were inconsistent showing significance in two out of three cropping seasons. Relationships between GY and TKM, DHE and CT were inconsistent reaching significance in one out of three cropping seasons. These results suggested the dependence of these relationships on the environment for their expression. The correlation between GY and CT indicated that this relationship is likely expected under stress rather than under non stress environment. So, to be efficient, selection based on CT should be done under stress conditions which allow expression of CT controlling genes. No significant correlations were observed between GY and RWC, PHT, MTS, CHL and ELWL (Table 3). The results of the correlation coefficients analysis indicated that that GY is influenced consistently by SN, while the effects of BIO, NKS, TKM, DHE, HI, CT on GY were environment-driven. GY was insensitive to the expressed variation of the physiological traits (RWC, PHT, MTS, CHL and ELWL). This contrasts with what has been reported by Awan et al. (2015) who observed that GY was closely linked to RWC and MTS. Lopes et al., (2012) noted that RWC failed to correlate to GY, while Nouri et al. (2011) concluded that RWC is a valuable analytical selection tool to improve wheat GY under drought stress.

Phenotypic correlations depend on genetic and en-

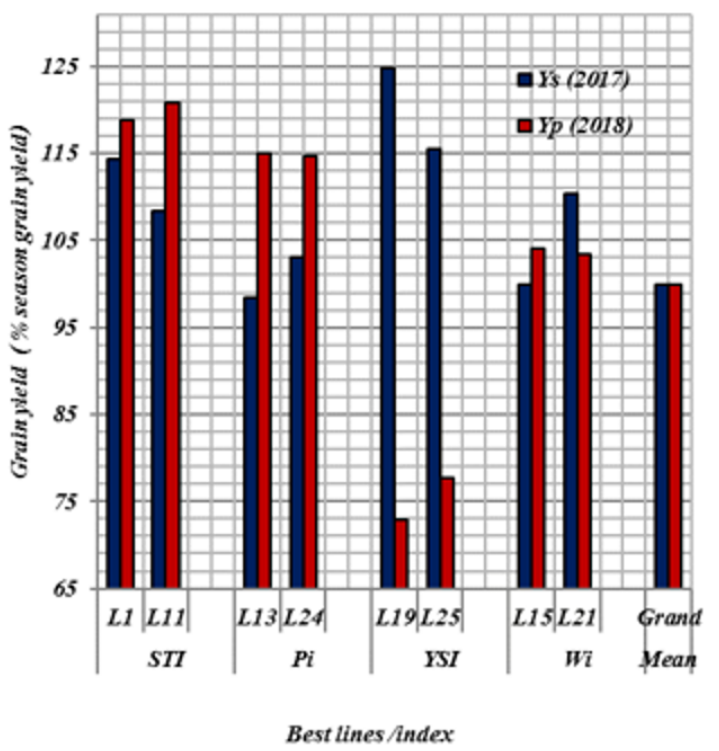

Figure 3: Grain yield performances ( $\mathrm{g} \mathrm{m}^{-2}$, left figure and \% of season grain yield, right figure) under stress (Ys) and non stress (Yp) growth conditions of the best breeding lines selected based on stress indices. 
Table 3: Person's correlation coefficients between grain yield and morpho-physiological traits of the advanced durum wheat breeding lines tested during three successive cropping seasons $(2016 / 17,2017 / 18,2018 / 19)$ at the ITGC- AES experimental site (Setif, Algeria).

\begin{tabular}{|c|c|c|c|}
\hline & GY 2016/17 & GY 2017/18 & GY $2018 / 19$ \\
\hline $\mathrm{SN}$ & $0.446^{*}$ & $0.641^{\star *}$ & $0.615^{\star *}$ \\
\hline TKM & $-0.099^{\mathrm{ns}}$ & $-0.392^{\mathrm{ns}}$ & $0.421^{\star}$ \\
\hline NKS & $0.700^{* *}$ & $0.583^{\star *}$ & $0.232^{\mathrm{ns}}$ \\
\hline DHE & $-0.096^{\mathrm{ns}}$ & $-0.158^{\mathrm{ns}}$ & $-0.503^{\star}$ \\
\hline $\mathrm{BIO}$ & $0.408^{\star}$ & $0.693^{* *}$ & $0.292^{\text {ns }}$ \\
\hline HI & $0.661^{\star *}$ & $0.211^{\mathrm{ns}}$ & $0.437^{\star}$ \\
\hline PHT & $0.032^{\mathrm{ns}}$ & $-0.274^{\mathrm{ns}}$ & $0.293^{\text {ns }}$ \\
\hline RWC & $0.054^{\mathrm{ns}}$ & $-0.178^{\mathrm{ns}}$ & $0.002^{\mathrm{ns}}$ \\
\hline MTS & $-0.114^{\mathrm{ns}}$ & $-0.143^{\mathrm{ns}}$ & $-0.040^{\mathrm{ns}}$ \\
\hline CHL & $0.124^{\mathrm{ns}}$ & $-0.109^{\mathrm{ns}}$ & $-0.246^{\mathrm{ns}}$ \\
\hline $\mathrm{CT}$ & $-0.410^{\star}$ & $-0.153^{\mathrm{ns}}$ & $-0.220^{\mathrm{ns}}$ \\
\hline ELWL & $-0.163^{\mathrm{ns}}$ & $-0.069^{\mathrm{ns}}$ & $-0.103^{\mathrm{ns}}$ \\
\hline r $5 \%, 23 \mathrm{DF}=$ & & 0.396 & \\
\hline $\mathrm{r} 1 \%, 23 \mathrm{DF}=$ & & 0.505 & \\
\hline
\end{tabular}

$\mathrm{GY}=$ Grain yield $\left(\mathrm{g} \mathrm{m}^{-2}\right), \mathrm{SN}=$ Number of spikes $\mathrm{m}^{-2}, \mathrm{TKM}=1000$-kernel mass $(\mathrm{g}), \mathrm{NKS}=$ Number of kernels per spike, $\mathrm{DHE}=$ Number of days to heading, $\mathrm{BIO}=$ Above ground biomass $\left(\mathrm{g} \mathrm{m}^{-2}\right), \mathrm{HI}=$ Harvest index $(\%)$, PHT = Plant height $(\mathrm{cm}), \mathrm{RWC}=$ Flag leaf relative water content, MTS $=$ Membrane thermo stability $(\%), \mathrm{CHL}=$ Chlorophyll content $(\mathrm{cci}), \mathrm{CT}=\mathrm{Canopy}$ temperature $\left({ }^{\circ} \mathrm{C}\right)$, ELWL $=$ Excised leaf water loss (\%). ns, ${ }^{\star}$ and ${ }^{\star *}=$ non-significant and significant effects at $5 \%$ and $1 \%$ probability level, respectively, r $5 \%$ and $\mathrm{r} 1 \%,=\mathrm{r}$ table values at 5 and $1 \%$ probability levels, respectively.

vironmental factors. Environmental factors may either enhance traits relationship or inhibit it, lessening the usefulness of such environment-driven traits in selection. The dependence of the relationship between traits on the environment was mentioned by Lopes et al., (2012) who found that TKM was positively associated with GY in some environments and negatively related in others environment, while CT was consistently associated with GY in all environments test. Furthermore, the absence of correlation between the independent and dependent variable could be due to the fact that the independent variable influences the dependent variable indirectly via other variables, rather than directly. These effects are not shown by the correlation coefficient. This inconvenient is avoided by using path analysis instead of the correlation coefficient analysis. In fact, path coefficient analysis subdivides the correlation coefficient into direct and indirect components, which allows determining which component influences substantially the dependent variable. Direct and indirect effects of the measured traits on grain yield are reported in table 4 . Based on the categorization of the path coefficients suggested by Bhisma (2016) (absolute value $<0.100$ is a negligible effect; $<0.300>0.100$, small effect; $>0.300<0.500$, medium effects, and $>0.500$ is a large effect), the results of the present study indicated that NKS (0.738), SN (0.614), TKM (0.434), BIO (0.349) and HI (0.290), beside their appreciable direct effects, are a consistent route via which most of the measured traits influenced indirectly grain yield. This highlights their role as GY determinants. In fact, SN exhibited a large positive direct effect (0.614) on GY, and acted indirectly, on this trait, via NKS (-0.263) and BIO (0.218). The negative indirect effect via NKS comes out because of compensation effect between SN and NKS. This suggests that increased GY is amenable through selection for high SN. This trait, easily estimated visual, could be used to discriminate between assessed lines in the field. Khan et al. (2010) reported positive direct and indirect effects through PHT, NKS and TKM of SN on GY. TKM expressed moderate direct effect (0.434) on GY, associated with sizeable indirect and negative effects via NKS (-0.440). The indirect effects of this trait via the remaining measured traits were negligible. In contrast Khan et al. (2010) found a negative direct effect for TKM, associated to negative indirect effects via PHT and NKS. NKS influenced positively GY directly (0.738) and indirectly and negatively via SN $(-0.219)$ and TKM $(-0.259)$. No substantial indirect effects of NKS via the remaining measured traits were observed (Table 4). DHE showed negligible direct influence on GY (-0.095), since lateness affected negatively GY through SN (-0.229) and TKM (-0.295) decline, and through increase of spike fertility (indirect effect for $\mathrm{NKS}=0.390)$. BIO acted directly (0.349) and indirectly via HI (-0.151) and via SN (0.383). 


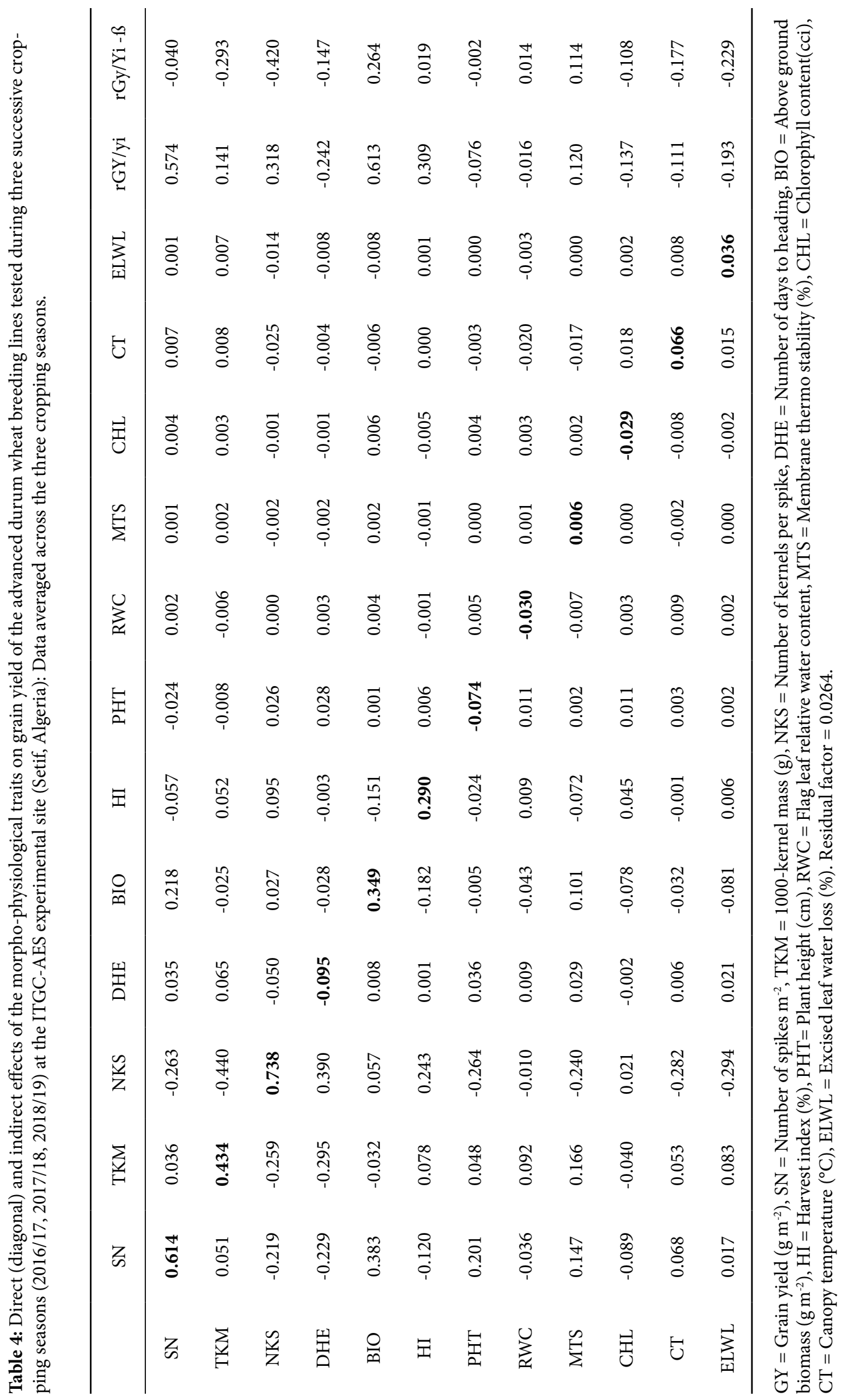


This trait showed negligible indirect effects via the other measured traits. Similarly, HI acted directly (0.290) and indirectly and negatively via BIO (-0.182), and via SN $(-0.120)$ and positively via NKS $(0.243)$. PHT showed sizeable indirect effects, positive via SN (0.201) and negative via NKS (-0.234). Khan et al. (2010) found positive direct effect of NKS on GY and positive indirect effects through PHT and TKM. The morphological traits measured (SN, TKM, NKS, DHE, BIO, HI and PHT) didn't express any sizeable indirect effect on GY via physiological traits. Similarly, physiological traits (RWC and CHL) didn't show any sizeable direct or indirect effects on GY, while MTS and CT and ELWL expressed moderate indirect effects. MTS affected indirectly and positively GY via SN (0.147) and via TKM (0.166) and negatively via NKS (-0.240). Similarly, CT (-0.282) and ELWL (-0.294) affected indirectly and negatively GY via NKS (Table 4). Globally these results suggested SN, NKS and BIO and HI should of interest to the breeding because of their role as GY determinants. These results corroborated those of Wolde et al. (2016) who found that HI and BIO impacted directly and indirectly GY, suggesting that these characters should be considered for selection either individually or combined under the form of an index.

\subsection{TRAITS AND BREEDING LINES STRUCTURATION}

Principal components analysis (PCA) grouped the recorded traits into 10 components, from which six exhibited an eigenvalue greater than unity, ranging from 4.03 for the first component to 1.30 for the sixth one. The retained principal components (PC) explained 23.7, $18.3,10.9,10.4,8.5$ and $7.6 \%$, respectively, with a cumulated variance reaching $79.45 \%$. The variability of the assessed breeding lines was interpreted based on the retained PC which indicated which of the measured traits were decisive in genotype differentiation. Based on their loading values, GY (0.474), STI (0.408), SN (0.345) and $\mathrm{Pi}(-0.438)$ were structured within the first component (PC1), while TKM (0.394), NKS (-0.516) and DHE $(-0.418)$ determined the second component (PC2, Figure $4)$. BIO (0.418) and HI (-0.601) were well correlated with PC3.The physiological trait MTS (-0.423), and the stress indices YSI (0.416) and $\mathrm{W}^{2} \mathrm{i}(0.522)$ were well represented on PC4. RWC (-0.417), CT (0.498) and ELWL (0.460) were more related to PC5, and PHT (-0.535) and CHL (0.420) were related to PC6. Based on traits assignation, PC1 could be used to target breeding lines with high GY, dynamic stability (high STI and low Pi indices value) and high SN. PC2 informs about breeding lines having high TKM, early to head but showing low NKS or lines having low TKM, late to head with high NKS (Figure 4). PC3 is a linear function of $\mathrm{BIO}$ production ability and partitioning $(\mathrm{HI})$.

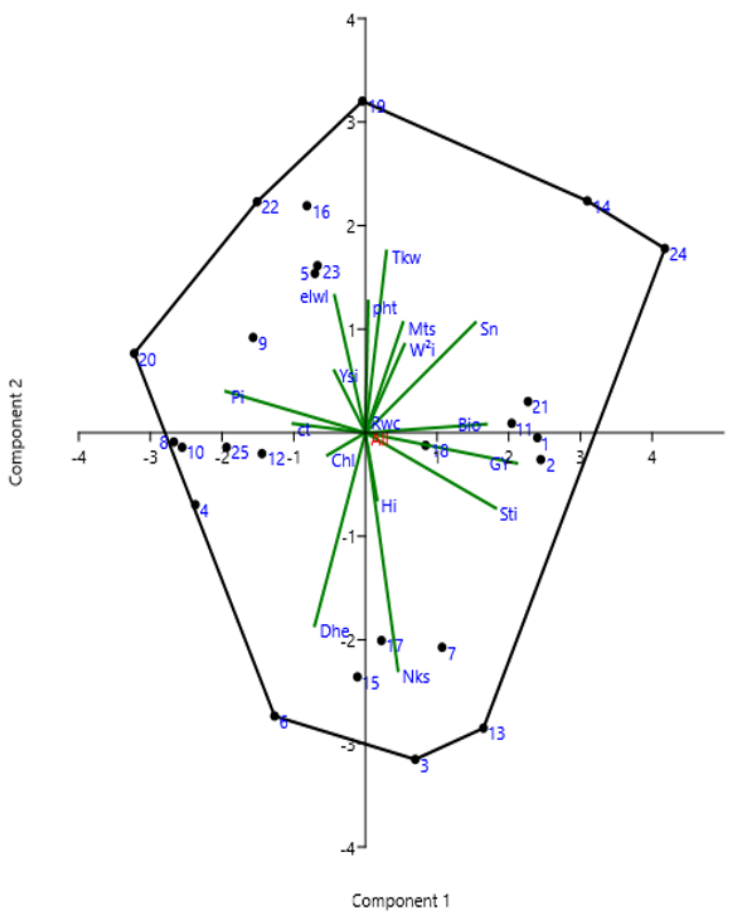

Figure 4: First two principal components $(\mathrm{PC} 1,23.7 \%$ and $\mathrm{PC} 2=18.3 \%$ ) biplot of the 25 durum wheat breeding lines based on standardized mean values of the morpho-physiological traits and stress indices. 
Breeding lines expressing high heat tolerance (MTS) and yield stability could be found along PC4, lines characterized by high water status, low canopy temperature and low excised leaf water loss are present along PC5. Short stem breeding lines with high stay green ability could be looked for along PC6. Analysis of the relationships between the loaded variables and the differentiation of the breeding lines trait indicated that lines L1 (2.400), L2 (2.447), L11 (2.042), L14 (3.096), L21 (2.269) and L24 (4.178) with high positive scores on PC1 grouped separately from lines L4 (-2.375), L8 (-2.674), L10 (-2.558), L12 (-1.444) and L20 (-3.226) with negative scores along PC1 (Figure 4). Group of lines with positive scores gained, relatively to the mean value of the group of lines with negative scores, $21.40 \% \mathrm{GY}, 11.43 \% \mathrm{SN}$, $27.98 \%$ BIO, 73.07 \% STI, -6.47 \% CT, -17.93 \% ELWL and $-49.56 \% \mathrm{Pi}$. Compared to the check cultivar Waha (L1), only L24 showed sizeable GY advantage (17.09\%), concomitant to a series of increases in TKM (19.94\%), HI (31.05\%), superiority genotypic (-95.61\%), stress sensitivity (-12.99\% reduction in STI), contribution to GEI (17.97\% increase in $\left.\mathrm{W}^{2} \mathrm{i}\right)$ and a slight reduction in BIO (-5.48 \%). Based on its high GY ability L24 appears as a potential candidate for future release. From the group of lines well represented on PC2, L22 (2.231) had positive score and grouped separately from L3 $(-3.155)$, L6 (-2.736), L7 (-7.072), L13 (-2.853), L15 (2.357) and L17 (-2.007) which had negative scores. These groups of lines diverge mainly for TKM and NKS. L22 appeared as potential genetic source to improve TKM $(12.15 \%$ increase over the check TKM mean), while L3, L6, L7, L13, L15 and L17 are good genetic sources of genes controlling spike fertility (12.78 to $17.77 \%$ increase over check NKS mean), without any penalty on TKM (variation in TKM relative to check mean ranged from -1.41 to 4.94 \%). Along PC3 were opposed line L5 (2.317) to line L18 $(-2.198)$ which diverged essentially for BIO (15.10\% higher in L5 compared to L18) and HI (-21.80 \% low in L5 compared to L18). Compared to the check cultivar, line L5 brought no sizeable change in BIO, nor in $\mathrm{HI}$, but $-14.40 \%$ GY decline, while L18 exhibited no significant change in GY compared to the check but a decline in BIO (-16.20 \%) and an increase in HI (+20.00\%). L18 appears as a good genetic source for future uses aiming to improve HI. Lines L16, L19 and L25 which were more related to PC4, as well as those related to PC5 (L9) and PC6 (L23) are less desirable as far as GY is concerned, in fact they yielded 6.54 to $14.66 \%$ less than Waha, but L16 exhibited $10.02 \%$ increase in MTS over Waha, associated with a decrease in YSI (-29.52\%), while L19 and L25 showed improvement in YSI over the check without sizeable change in MTS. L9 exhibited a decrease in CHL and $\mathrm{L} 9$ a reduction in ELWL. Based on these results, the assessed breeding lines were classified, at half way the maximum distance, into 5 clusters (Figure 5). The line L19 stemmed alone in a separate cluster, this line is a sister line to L25, whose cross pedigree is Ouasloukosl/5/ Aznl/4Bezaizshf//SD19539/Waha/3/Gdr ${ }_{2}$.

Cluster 2 included 9 lines (L25, L5, L22, L16, L20, L4, L8, L10 and L12). The cluster 3 contains 5 lines (L1, L2, L11, L14, and L24). L14 and L24 are sister lines with a cross pedigree Terbol $_{975} /$ Geruftel $_{2}$. Cluster 4 included 3 lines (L21, L9 and L23), while cluster 5 included 7 lines (L17, L18, L7, L15, L6, L3 and L13). L3 and L23 are sister lines with a cross pedigree Sooty9/Rascon37//Storlom/5/ Toska26/Rasco. The check cultivar Waha was included in cluster 3 (Figure 5). Deviation of the mean values of clusters $\mathrm{C} 1, \mathrm{C} 2, \mathrm{C} 3$, and $\mathrm{C} 5$, in \%, from the mean values of the lowest grain yield cluster $\mathrm{C} 4$ are reported in Table 5. Compared to $\mathrm{C} 4$, breeding lines grouped in $\mathrm{C} 3$ showed appreciable increases in GY (13.06\%), BIO (17.72\%) and SN (20.15\%), associated with $10.76 \%$ TKM decrease. They are stress tolerant and stable in the dynamic sense (23.94 \% increase in STI, 39.6 \% decrease in $\mathrm{Pi}$ ), reacting to environment changes $\left(210.72 \%\right.$ increase in $\left.\mathrm{W}^{2} \mathrm{i}\right)$. Among the lines included in this cluster the sister lines L24 and L14 were scored as the best lines for 7 (GY, SN, DHE, HI, PHT, CHL and Pi) and 5 traits (GY, BIO, DHE, PHT, and MTS) out 17 measured characters, respectively. Both lines are considered for released as cultivars, and may be used as parents in crosses to take advantage of the desirable characteristics they brought. L2 was scored as the best for its high RWC, and as such could be used as a genetic source for improving this characteristic in elite material. Similarly, L11, scored best for STI, could be crossed to transfer its stress tolerance and good yielding ability under stress and non stress conditions to advanced breeding plant material. L19 which stemmed alone as a cluster is sensitive to environmental changes (high $\mathrm{W}^{2} \mathrm{i}$ ) but was scored among the best for its ability to minimize GY reduction under stress conditions (high YSI value), and thus could be used in crosses as a source of germplasm to increase genetic variability of this characteristic in the segregating populations. Breeding lines included in cluster $\mathrm{C} 4$ are globally low grain yielding, but L9 from this cluster was scored as having the lowest CT, so it could be useful as a source for this desirable trait. Similarly, lines included in $\mathrm{C} 5$, are lower grain yield in general but some lines contain genes controlling desirable characteristics such as high RWC in L18 and low ELWL in lines L3 and L6.

Globally and as far as the objective of this study is concerned, the results indicated that if GY, BIO, SN, TKM, NKS and indices based on GY are more or less 


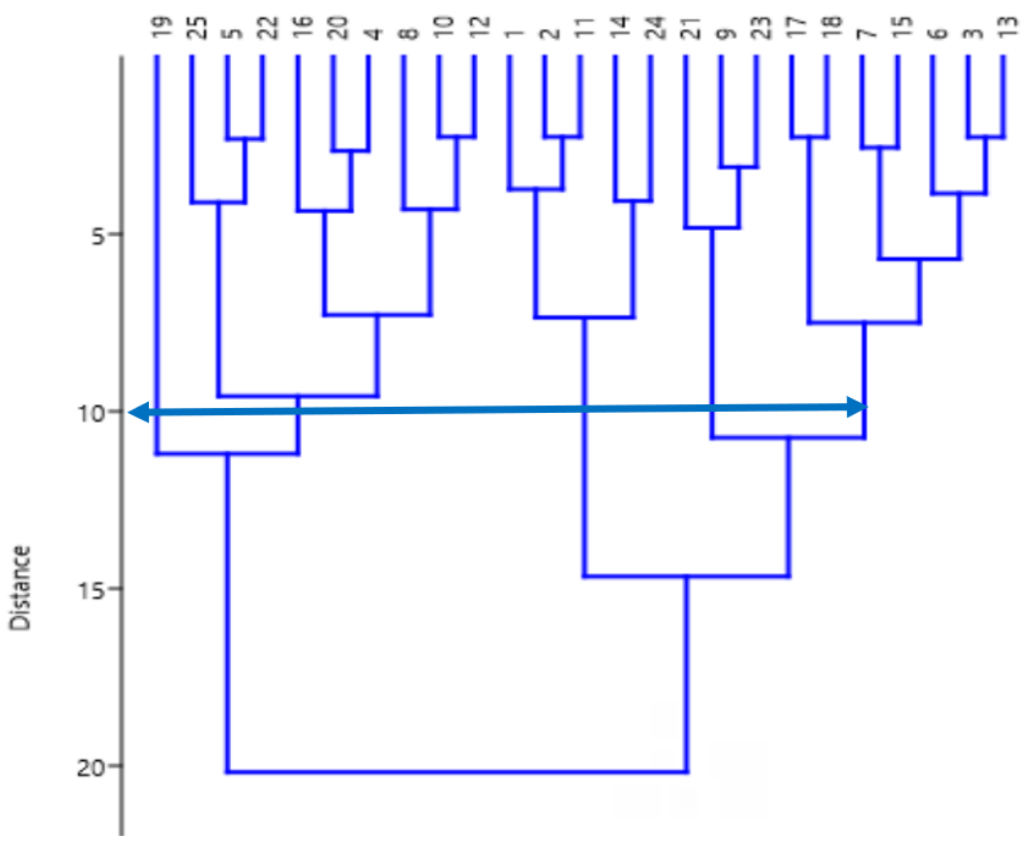

Figure 5: Clustering of the 25 durum wheat breeding lines based on standardized mean values of the morpho-physiological traits and stress indices.

Table 5: Deviation $\left[\left(100 *\left(\mathrm{X}_{\mathrm{Ci}}-\mathrm{X}_{\mathrm{C} 4}\right) / \mathrm{X}_{\mathrm{C} 4}\right)\right]$ of the mean values of clusters $\mathrm{C} 1(=\mathrm{L} 19), \mathrm{C} 2, \mathrm{C} 3$ and $\mathrm{C} 5$ as \% of the mean values of the lowest yielding cluster $\mathrm{C} 4$ for the measured traits and stress indices.

\begin{tabular}{lcccccc}
\hline & C3 & C5 & L19 & C2 & Mean C4 & Mean check (L1) \\
\hline GY & 13.05 & 5.44 & 1.4 & -8.7 & 667.1 & 715.8 \\
BIO & 17.73 & 3.57 & 6.5 & -3.5 & 469.2 & 568.3 \\
SN & 20.15 & 4.17 & 14.6 & 6.8 & 40.2 & 33.6 \\
NKS & 1.73 & 15.39 & -9.4 & -4.5 & 34.6 & 35.1 \\
TKM & -10.76 & -14.14 & -4.3 & -10.9 & 114.3 & 115.1 \\
DHE & -0.07 & 1.32 & 0.2 & 0.9 & 1585.4 & 1883.1 \\
HI & -4.62 & 2.09 & -3.5 & -4.1 & 41.0 & 36.3 \\
PHT & 2.22 & -0.83 & 2.6 & 1.6 & 67.7 & 68.4 \\
RWC & -5.97 & -4.70 & -6.1 & -5.3 & 81.7 & 78.2 \\
MTS & -2.86 & -12.81 & -13.7 & -7.1 & 67.2 & 62.0 \\
CHL & 2.71 & 7.31 & 1.8 & 7.4 & 37.4 & 41.6 \\
TCV & 0.75 & 4.08 & 4.0 & 7.9 & 21.8 & 20.2 \\
ELWL & 1.95 & -18.00 & 39.9 & 6.1 & 37.5 & 35.9 \\
STI & 23.94 & 13.34 & -9.0 & -21.7 & 31.8 & 33.2 \\
Pi & -39.86 & -16.25 & 31.3 & 45.1 & 0.4 & 0.3 \\
YSI & -22.15 & -17.11 & 48.7 & -10.9 & 0.3 & 0.4 \\
Wi & 210.72 & 85.16 & 957.2 & 52.8 & 11.4 & 45.0 \\
\hline
\end{tabular}

$\mathrm{GY}=$ Grain yield $\left(\mathrm{g} \mathrm{m}^{-2}\right), \mathrm{BIO}=$ Above ground biomass $\left(\mathrm{g} \mathrm{m}^{-2}\right), \mathrm{SN}=$ Number of spikes $\mathrm{m}^{-2}, \mathrm{NKS}=$ Number of kernels per spike, $\mathrm{TKM}=1000$ - kernel mass (g), DHE = Number of days to heading, HI = Harvest index $(\%)$, PHT $=$ Plant height $(\mathrm{cm}), \mathrm{RWC}=$ Flag leaf relative water content, MTS = Membrane thermo stability $(\%), \mathrm{CHL}=$ Chlorophyll content $(\mathrm{cci}), \mathrm{CT}=\mathrm{Canopy}$ temperature $\left({ }^{\circ} \mathrm{C}\right), \mathrm{ELWL}=$ Excised leaf water loss $(\%), \mathrm{STI}=$ Stress tolerance index, $\mathrm{Pi}$ = genotypic superiority index, $\mathrm{YSI}=\mathrm{Grain}$ yield stability index, $\mathrm{W}^{2} \mathrm{i}=$ ecovalence. 
correlated and easily accumulated in the plant materials, physiological traits on the contrary were unrelated to each other and to the first cited traits making difficult the concomitant selection for yield and stress tolerance driven by these traits. This is because selection is done under favorable conditions based mainly on GY. Under these conditions, physiological traits, markers of stress tolerance, are less expressed and not selected for. To bring altogether these traits and agronomic ones in the same genetic background, it is necessary to make complexes crosses between parents carefully chosen for these specific characteristics to enhance favorable genetic linkage and to generate new basic segregating populations with high genetic variability for these traits.

\section{CONCLUSIONS}

Even though the season main effect was the most preeminent source of variation, the results of the combined analysis of variance showed sufficient variability for most of the measured traits, justifying deeper analyses of the data. STI and Pi identify stress tolerant and high performing lines under Ys and Yp environments, showing wider adaptability. YSI is best suited to select drought tolerant lines which minimize grain yield reduction under stress but which are not responsive to fertility, showing biological stability. $\mathrm{Wi}^{2}$ is best suited to select lines with reduced contribution to GEI. Both YSI and $\mathrm{W}^{2} \mathrm{i}$ identify lines with specific adaptation. Based on correlation coefficients analysis GY showed a consistent correlation with $\mathrm{SN}$, while its relationships with the remaining agro-morphological traits were inconsistent and environmentallydriven. The relationships with physiological traits were in most cases non significant. Path analysis results showed that BIO and HI, SN and to lesser extent NKS influenced directly GY, besides being a consistent route via which most of the measured traits influenced indirectly grain yield, suggesting that these traits should of interest to the breeding because. Physiological traits didn't show any sizeable direct effect on GY, their indirect effects were of varying sign and magnitude, via $\mathrm{BIO}$ and $\mathrm{HI}$. Six PC explained altogether nearly $80.00 \%$ of the total variation available in the data. PC1 was a function of GY, STI, SN and Pi. TKM, NKS and DHE were grouped within PC2. $\mathrm{BIO}$ and HI were well correlated with PC3. MTS, YSI and $\mathrm{W}^{2} \mathrm{i}$ were represented on PC4 RWC, CT and ELWL were related to PC5, and PHT and CHL to PC6. Breeding lines dispersed along PC1 exhibited substantial differences in performances and stress tolerance abilities, among those lines L24 showed sizeable GY advantage which suggests it a potential candidate for future release. Potential genetic sources to improve morpho-physiological traits were identified on the retained PC's. The various breeding lines were grouped into 5 clusters. Breeding lines grouped in C3 were, in general, high yielding and stress tolerant, within this cluster L24 and L14 were scored as the best lines for 7 and 5 traits out of 17 measured characters, respectively. Both lines may be used as parents in crosses to take advantage of the desirable characteristics they brought. Globally and as far as the objective of this study is concerned, the results indicated that physiological traits were unrelated to each other and to morphological traits making difficult the concomitant selection for yield and stress tolerance driven by these traits. To bring altogether these traits and agronomic ones in the same genetic background, it is necessary to make complexes crosses between parents carefully chosen for these specific characteristics to enhance favorable genetic linkage and to generate new basic segregating populations with high genetic variability for these traits.

\section{REFERENCES}

Akintunde, A. N. (2012). Path analysis step by step using excel. Journal of Technical Science and Technologies, 1, 9-15.

Annicchiarico, P., Abdellaoui, Z., Kelkouli, M., \& Zerargui, H. (2005). Grain yield, straw yield and economic value of tall and semi-dwarf durum wheat cultivars in Algeria. Journal of Agricultural Science, 143(1), 57-64. https://doi. org/10.1017/s0021859605004855

Asharaf, M. (2010). Inducing drought tolerance in plants: recent advances. Biotechnology Advances 28(1), 199-238. https://doi.org/10.1016/j.biotechadv.2009.11.005

Awan, K.A., Ali, J., \& Akmal, M. (2017). Yield comparison of potential wheat varieties by delay sowing as rainfed crop for Peshawar climate Sarhad Journal of Agriculture, 33(3), 480-488. https://doi.org/10.17582/journal. sja/2017/33.3.480.488

Benmahammed, A., Nouar, H., Haddad, L., Laala, Z., \& Bouzerzour, H. (2010). Analyse de la stabilité des performances de rendement du blé dur (Triticum durum Desf.) sous conditions semi-arides. Biotechnologie, Agronomie, Société et Environnement, 14, 177-186.

Bhisma, M. (2016). How to conduct path analysis and structural equation model for health research. International Conference on Public Health Best Western Premier Hotel, Solo, Indonesia, September 14-15, Masters Program in Public Health, Graduate Program. Sebelas Maret University, Indonesia.

Ceccarelli, S., Acevedo, E., \& Grando, S. (1991). Breeding for yield stability in unpredictable environments: single traits, interaction between traits, and architecture of genotypes. Euphytica, 56(2), 169-185. https://doi.org/10.1007/ bf00042061

CEIC. 2021. Algeria's Durum Wheat production from 1975 to 2017. Retrieved from https://www.ceicdata.com/en/algeria/agricultural-production/agriculture-production-vegetable-cereals-durum-wheat 
Chamekh, Z., Karmous, C., Ayadi, S., Sahli, A., Hammami, Z., Belhaj Fraj, M., ...... \& Slim-Amara, H. (2015). Stability analysis of yield component traits in 25 durum wheat (Triticum durum Desf.) genotypes under contrasting irrigation water salinity. Agricultural Water Management, 152, 1-6. http://dx.doi.org/10.1016/j.agwat.2014.12.009

Clarke, J. M., Richards, R. A., \& Condon, A. G. (1992). Effect of drought stress on residual transpiration and its relationship with water use of wheat. Canadian Journal of Plant Science, 71(3), 695-702. https://doi.org/10.4141/cjps91-102

CropStat 7.2. (2008). Software package for windows. Manila, International Rice Research Institute (IRRI).

Cruz, C. D., Regazzi, A. I., \& Carneiro, P. C. S. (2012). Modelos biométricos aplicados ao melhoramento genético. $4^{\text {th }} \mathrm{Ed}$. UFV, Viçosa.

Dhanda, S. S., \& Sethi, G. S. (1998). Inheritance of excised-leaf water loss and relative water content in bread wheat (Triticum aestivum L). Euphytica, 104(1), 39-47. https://doi. org/10.1023/a:1018644113378

Di Matteo, J. A., Ferreyra, J. M., Cerrudo, C., Alejandro, A., Echarte, L., \& Fernando, H. (2016). Yield potential and yield stability of Argentine maize hybrids over 45 years of breeding. Field Crops Research, 197, 107-116. https://doi. org/10.1016/j.fcr.2016.07.023

Dorostkar, S., Dadkhodaie, A., \& Heidari, B. (2015). Evaluation of grain yield indices in hexaploid wheat genotypes in response to drought stress. Archives of Agronomy and Soil Science, 61(3), 397-413. https://doi.org/10.1080/03650340 .2014 .936855

Farshadfar, E., Poursiahbidi, M. M., \& Safavi S. M. (2018). Assessment of drought tolerance in land races of bread wheat based on resistance/ tolerance indices. International Journal of Advanced Biological and Biomedical Research, 6, 233-245.

Fraser, E.A.B., Simelton, E., Termansen, M.S., Gosling, N., \& South, A. (2013). Vulnerability hotspots": Integrating socioeconomic and hydrological models to identify where cereal production may decline in the future due to climate change induced drought. Agricultural and Forest Meteorology, 170, 195-205. https://doi.org/10.1016/j.agrformet.2012.04.008

Golabadi, M., Arzani, A. S., \& Maibody, A. M. (2006). Assessment of drought tolerance in segregating populations in durum wheat. African Journal of Agricultural Research, 5, 162-171.

Grzesiak M.T., Marcińska, I., Janowiak, F., Rzepka, A., \& Hura, T. (2012). The relationship between seedling growth and grain yield under drought conditions in maize and triticale genotypes. Acta Physiologiae Plantarum, 34(5), 1757-1764. https://doi.org/10.1007/s11738-012-0973-3

Grzesiak, M.T., Hura, K., Jurczyk, B., Hura, T., Rut, G., Szczyrek, P., \& Grzesiak, S. (2017). Physiological markers of stress susceptibility in maize and triticale under different soil compaction and/or soil water contents. Journal Plant Interaction, 12(1), 355-372. https://doi.org/10.1080/17429 145.2017.1370143

Haddad, L., Bouzerzour, H., Benmahammed, A., Zerargui, H., Hannachi, A., Bachir, A., ........\& Laala, Z. (2016). Analysis of genotype $\times$ environment interaction for grain yield in early and late sowing date of Durum Wheat (Triticum $d u$ - rum Desf.) genotypes. Jordan Journal of Biological Sciences, 8(3), 139-146. https://doi.org/10.4314/jfas.v8i3.19

Hammer, O., Harper, D.A.T., \& Ryan, P. D. (2001). PAST: Paleantological statistics software package for education and data analysis. Palaeontologia Electronica, 4, 1-9.

Hasheminasab, H., Farshadfar, E., \& Varvani, H. (2014). Application of physiological traits related to plant water status for predicting yield stability in wheat under drought stress conditions. Annual Review \& Research in Biology, 4(5), 778-789. https://doi.org/10.9734/arrb/2014/6689

Hura, T., Hura, K., Grzesiak, M. T., \& Rzepka, A. (2007). Effect of long-term drought stress on leaf gas exchange and fluorescence parameters in C3 and C4 plants. Acta Physiologiae Plantarum, 29(2), 103-113. https://doi.org/10.1007/ s11738-006-0013-2

Ibrahim, A., \& Quick, J. S. (2001). Genetic control of high temperature tolerance in wheat as measured by membrane stability. Crop Science, 41(5), 1405-1407. https://doi. org/10.2135/cropsci2001.4151405x

Khajuria, P., Singh, A. K., \& Singh, R. (2016). Identification of heat stress tolerant genotypes in bread wheat. Electronic Journal of Plant Breeding, 7(1), 124-131. https://doi. org/10.5958/0975-928x.2016.00016.8

Khan, F., Azam, A., \& Ali, A. (2010). Relationship of morphological traits and grain yield in recombinant inbred lines grown under drought conditions. Pakistan Journal of Botany, 42(1), 259-267.

Li, P., Chen, J., \& Wu, P. (2011). Agronomic characteristics and grain yield of 30 spring wheat genotypes under drought stress and non-stress conditions. Agronomy Journal, 103(6), 1619-1628. https://doi.org/10.2134/agronj2011.0013

Lin, C. S., Binns, M. R., \& Lefkovitch, L. P. (1986). Stability analysis: where do we stand? Crop Science, 26(5), 894-900. https:// doi.org/10.2135/cropsci1986.0011183x002600050012x

Lin, C.S., \& Binns, M.R. (1988). A superiority measure of cultivar performance for cultivar $\times$ location data. Canadian Journal of Plant Science, 68(1), 193-198. https://doi. org/10.4141/cjps88-018

Lobell, D. B., \& Field, C. B. (2007). Global scale climate-crop yield relationships and the impacts of recent warming. Environmental Research Letters, 2(1), 1-7. https://doi. org/10.1088/1748-9326/2/1/014002

Lopes, M.P., Reynolds, M.P., Jalal-Kamali, M.R., Moussa, M., Feltaous, Y., Tahir, I.S.A., .....\& Baum, M. (2012). The yield correlations of selectable physiological traits in a population of advanced spring wheat lines grown in warm and drought environments. Field Crops Research, 128, 129-136. https://doi.org/10.1016/j.fcr.2011.12.017

Marcinska I, Czyczyło-Mysza, I., Skrzypek, E., Grzesiak, M., Popielarska Konieczna, M., Warchoł, M., \& Grzesiak, S. (2017). Application of photochemical parameters and several indices based on phenol-typical traits to assess intra-specific variation of oat (Avena sativa L.) tolerance to drought. Acta Physiologiae Plantarum, 39(7), 1-13. https:// doi.org/10.1007/s11738-017-2453-2

Mohammadi, R., Sadeghzadeh, D., Armion, M., \& Amri, A. (2011). Evaluation of durum wheat experimental lines under different climate and water regime conditions of 
Iran. Crop and Pasture Science, 62(2), 137-151. https://doi. org/10.1071/cp10284

Nouri, A., Etminan, A., Teixeira da Silva, J. A., \& Mohammadi, R. (2011). Assessment of yield, yield related traits and drought tolerance of durum wheat genotypes (Triticum turgidum var. durum Desf.). Australian Journal of Crop Science, 5(1), 8-16.

Pask A.J.D., Pietragala, J., Mullan, F.M., \& Reynolds, M.P. (2012). Physiological Breeding II: A field guide to wheat phenotyping. Mexico, DF, CIMMYT.

Saed-Moucheshi, A., Hasheminasab, H., \& Assad, M. T. (2016). Modeling the relationships between yield stability and its related physio-biochemical traits under water deficit conditions in wheat. Biharean Biologist, 10, 123-130.

Sio-Se Mardeh, A., Ahmadi, A., Poustini, K., \& Mohammadi, V. (2006). Evaluation of drought resistance indices under various environmental conditions. Field Crop Research, 9, 222-229.

Wahid, A., Gelani, S., Asharf, M., \& Foolad, M. R. (2007). Heat tolerance in plants: An overview. Environmental and Experimental Botany, 61(3), 199-223. https://doi.org/10.1016/j. envexpbot.2007.05.011

Weedon, O. D., \& Finckh, M. R. (2019). Heterogeneous winter wheat populations differ in yield stability depending on their genetic background and management system. Sustainability, 11(21), 6172. https://doi.org/10.3390/su11216172

Wolde, T., Eticha, F., Alamerew, S., Assefa, E., \& Dutamo, D. (2016). Trait associations in some durum wheat (Triticum durum Desf.) accessions among yield and yield related traits at Kulumsa, South Eastern Ethiopia. Advances in Crop Science and Technology, 4(4), 234-237. https://doi. org/10.4172/2329-8863.1000234 